\title{
Heat storage wall made of concrete and encapsulated water applied to mass construction social housing in temperate climates
}

\author{
Graciela Melisa Viegas a,b,* Juan Ignacio Jodra ${ }^{\mathrm{a}, \mathrm{b}}$, Gustavo Alberto San Juan ${ }^{\mathrm{a}, \mathrm{b}}$, \\ Carlos Alberto Díscoli ${ }^{\mathrm{a}, \mathrm{b}}$ \\ a IIPAC-FAU-UNLP (Built Environment Policy Research Institute, School of Architecture and Planning of the National University of La Plata), Street $47 \mathrm{~N}$ \\ 162, DC 478, 1900 La Plata, Argentina \\ ${ }^{\mathrm{b}}$ National Scientific and Technical Research Council (CONICET)
}

\section{A R T I C L E I N F O}

\section{Article history:}

Received 3 October 2017

Accepted 1 November 2017

\section{Keywords:}

Solar energy

Technology

Social housing

Heat storage walls

\begin{abstract}
A B S T R A C T
In Argentina there is a serious housing shortage. The National State responds to this shortage in a quantitative rather than in a qualitative way, avoiding low maintenance architectural and technological solutions for this problem. For this purpose, the passive solar technologies are a truly viable alternative. Therefore, this work presents the design and thermal performance of heat storage walls (HSW) made of mixed materials (concrete and water) for heating mass construction housing built by the National State of Argentina. They are prepared to be included in modules $(1.2 \mathrm{~m} \times 2.4 \mathrm{~m})$ on the equator-facing sides since they are made of storage mass made with industrialized stackable pieces. The storage mass is made of concrete with encapsulated water in PVC pipes and it is covered with a single-glazed covering. In this work, the technological design, the industrialization, manufacture and assembly stages, and its performance are presented. Simulations of the systems incorporated into a house were carried out and they were then compared to the most widespread technologies (solid concrete walls). Experimental scale measurements of these systems were also made in a $1.08 \mathrm{~m}^{3}$ insulated enclosure. The simulations did not show very significant differences among the analyzed systems, but they allowed us to define the use of single glazing as a transparent covering. The measurements show the different loading dynamics of each type of wall and confirm a difference of $2^{\circ} \mathrm{C}$ among the internal temperatures, recorded inside the enclosures in favor of the mixed storage wall. The carried out works enabled us to install those systems in social housing in the Province of Buenos Aires, Argentina.
\end{abstract}

(C) 2017 Elsevier B.V. All rights reserved.

\section{Introduction}

According to the National Institute of Population, Homes, and Housing, the Republic of Argentina had 40,117,096 inhabitants, 12,171,675 homes, ${ }^{1}$ and 11,317,507 inhabited dwellings [1] in 2010. There has also been a serious structural housing shortage for a long time. A great number of families live in precarious houses or their houses have some kind of irregularity. According to the 2010 census data, $16.4 \%$ of the houses in the country have some type of deficiency. In general, the solutions offered by the State refer to housing quantitive shortage and, in very few cases, refer to the qualitative shortage to improve habitation. Energy efficiency is not considered in a crisis context related to the availability of

\footnotetext{
* Corresponding author.

1 Home: a group of people who live together in the same place and share food costs
}

non-renewable resources. It is clear that housing problems are not solved by only building new houses. It is necessary to improve the building process and the final results of mass construction housing, considering not only the operating costs but also their maintenance. Habitation and housing reality in Latin America shows an increasing deterioration in the population's quality of life, especially of those who have fewer resources. This is shown in growing housing shortage, disorganization and deterioration of urban and metropolitan areas, as well as in not very effective actions to preserve the housing stock and the environment [2].

Therefore, it is possible to say that the solutions for state housing in social areas with fewer economic resources in Argentina are based on producing low-cost designs, without paying so much attention to social, cultural and environmental aspects. In the Province of Buenos Aires - the most populated province of the country $(16,660,000$ inhabitants $)$ - there are particular situations in relation to this topic. On the one hand, users have technical, economic and physical difficulties to have access to conventional 
energy resources for air conditioning. On the other hand, the housing designs do not respond to the climate or to the future users' needs, and there is limited knowledge of the potentialities of the environmentally conscious technologies.

In this context, a viable solution to solve this problem is the possibility of producing social housing models with improvements in the above-mentioned qualitative aspects, and with the incorporation of easily implemented passive solar technologies with low-cost production at massive scale. If we focus on social housing and the means for its air conditioning, it is possible to say that heat storage walls are a feasible alternative. Heat storage walls are passive heating systems which make the most of the solar energy to reduce the buildings energy demand and operating costs. This type of globally developed systems is a good option for social housing buildings where users generally require housing with low operating costs to reduce the expenses of the buildings' use.

Heat storage walls made of solid materials are among these technologies. Their development in the world dates back to the end of the 19th century and, nowadays, they are still used and the most widespread technology. The different variations in the storage mass depend on the local climate, on the used materials, and on the requirements for the use of the technology. As regards the climate, the factors influencing the design are: the solar resource availability, the amount of sunshine duration, and the thermal range. There is a variety of designs incorporating materials in solid state, liquid state, or the so-called phase change materials (PCM). This makes it possible to vary the heat loading and transfer dynamics, and the volumetric heat capacity of these systems. The requirements for the use set out variations in relation to the storage level and thermal transfer, to the time lag capacity, and to the reduction of the thermal wave amplitude.

The beginning of this technology dates back to the precepts stated by Edward Morse, who patented his invention under US Patent 246626 code in 1881 . This technology uses the sun's radiant energy as heat source, which is stored as thermal energy in the solid materials exposed to the sun. This invention was spread in around 1960 as from the implementations made by Engineer Felix Trombe and Architect Jacques Michel in the passive houses of the French city Font-Odelilo-Via, located in the Eastern Pyrenees. Some decades later, some implementations were developed in the United States. These allowed investigators to establish basic criteria for the functioning and use of such systems in relation to simplified models of the involved complex physical and thermal phenomena, and they also allowed its implementation in buildings to happen [3-5]. In 1997, progress in the concrete walls original designs was observed when French researchers related to J. Michel incorporated an internal insulation to the traditional Trombe wall in order to avoid night losses and unwanted gains during the day [6].

In the last years, different investigations have shown the current concern for continuing researching the topic. The state of the art involves: studies of the passive storage systems global behavior [7-9], the development of special blocks to produce storage mass [10], the study of storage mass variations incorporating alternative and phase change materials [11-18], and the use of encapsulated water in the thermal mass [19]. Different types of walls, based on completely solid or completely liquid storage mass, have been studied in Argentina according to the climate (temperate or cold), and the type of implementation [20-23].

In relation to the global study of passive storage systems, Briga Sá [7] considers that more studies should be conducted to assess the real impact of Trombe walls integrated into buildings. It is concluded that energy-heating needs could be reduced by $16.36 \%$ if a Trombe wall is added to the building envelope. Other studies [8] have shown a more significant improvement of the building performance by using Trombe walls, since a reduction of about $20 \%$ in the annual energy need was obtained. The effect of incorporating adobe passive storage walls is also observed in different types of greenhouses and they confirm that their incorporation increases the reached temperatures in the studied area. However, the percentage is not specified [9]. It is possible to conclude that this type of research clarifies the scene in relation to the benefits of their use.

Regarding the structure of elements containing the storage mass, Zhang [10] develops walls with air cavities and analyses the behavior of the heat transfer and the storage capacity through equivalent mathematical models, and shows that the thermal conductivity of these walls depends on the shape of the cavity and on the percentage of air incorporated into the wall.

In several investigations, the specific study of the storage mass to improve the thermal performance of the storage walls and to deal with different climatic situations is reflected, for example, in the use of phase change materials (PCM). There are works on the revision of these materials' current situation to improve housing habitability [14]. In particular, they are comparisons of concrete storage mass with phase change materials in search for higher thermal inertia and better internal temperatures [15]. Similar studies in Iraq have shown that hydrated salt walls have more benefits for heating spaces than those made of concrete or paraffin [16], or when brick storage walls incorporating phase change materials are used to improve insulation and thermal comfort [17]. In [18], the experimental measurement and the numerical simulation of phase change materials (fatty acids, paraffin, and hydrated salt) encapsulated in glass bricks are carried out. The results show that phase change materials are good for regulating space heating. However, they show a significant temperature increase and make it necessary to conceive systems with PCM together with efficient night air circulation and solar income limitation. It is possible to conclude that phase change materials provide significant improvements for heating regulation, for temperature increase, and for obtaining higher thermal inertia. Despite their heat capacity increase because of the latent heat, they present some problems in relation to their cost and their useful life. For these reasons, its massive use in houses with little maintenance is not a very sustainable option, as is the case of social housing built by the state.

In this sense, the use of water as part of storage mass is presented as an interesting alternative to study. In Argentina, there are precedents for the design of heat storage walls with water mass and with controlled transfer [20]. This technology was implemented in the $80 \mathrm{~s}$ in a project called "Groups of High-Density Housing with Solar Energy Use" ["Conjunto de viviendas de alta densidad con utilización de energía solar"], from which a housing prototype was developed [24]. The winter determinants with which this technology was designed (located in the City of La Plata, Buenos Aires, Argentina) were: 994 heating degree-days (base temperature $18^{\circ} \mathrm{C}$ ); solar radiation between $10.5 \mathrm{MJ} / \mathrm{m} 2$ per day and $5.4 \mathrm{MJ} / \mathrm{m} 2$ per day; and changing relative sunshine duration. A temperature control system with high loading capacity (1956 liters stored in five-liter water containers, each of them displayed in staggered formation) was opportunely developed with high transfer capacity between storage mass and circulating air. The system was compact and with heat delivery control in accordance with the demand. This technology reached temperatures of $63^{\circ} \mathrm{C}$ and the heat storage capacity was approximately three days. The found difficulty was the need to design a hermetic enclosure for the storage wall with highly efficient insulation $[13,25,26]$.

The use of water combined with concrete is shown as progress on the described difficulties. In China, a solar house with traditional walls is compared with one provided with thermal storage walls with water insertions, observing an annual energy saving higher than $8 \%$ [19]. A passive solar house with a water thermal storage wall (WTSW) was especially studied, and its influence on the internal thermal environment was analyzed. Field measure- 
Table 1

Winter climatic conditions in a coastal city and in a city in the centre of the province of Buenos Aires. IRAM Regulation 11603.

\begin{tabular}{|c|c|c|c|c|c|c|c|c|c|}
\hline City & Latitude & Longitude & $\begin{array}{l}\text { Above sea level } \\
\mathrm{m}\end{array}$ & $\begin{array}{l}\text { Average Temp. } \\
{ }^{\circ} \mathrm{C}\end{array}$ & $\begin{array}{l}\text { Maximum Temp. } \\
{ }^{\circ} \mathrm{C}\end{array}$ & $\begin{array}{l}\text { Minimum Temp. } \\
{ }^{\circ} \mathrm{C}\end{array}$ & $\begin{array}{l}\text { Relative Humidity } \\
\%\end{array}$ & $\begin{array}{l}\text { Rain } \\
\text { mm }\end{array}$ & $\begin{array}{l}\text { Heating degree days } \\
\text { Base Temperature } 18^{\circ} \mathrm{C}\end{array}$ \\
\hline Azul (central area) & -36.8 & 59.8 & 132 & 7.7 & 14.2 & 2.4 & 84 & 42 & 1589 \\
\hline La Plata (coastal area) & -35.0 & 57.9 & 23 & 9.7 & 15 & 5.5 & 82 & 59 & 1178 \\
\hline
\end{tabular}

ments and numerical simulations were carried out. The results of the simulation and of the orthogonal analysis pointed out that, in comparison with the traditional wall, if the space is equipped with WTSW, the annual energy consumption could be reduced by $8.6 \%$ and the assessment index of the internal thermal comfort could be improved by $12.9 \%$. Moreover, water reacts successfully to temperate climates. As it is possible to observe, the energy consumption reduction is lower than in the previously analyzed cases, but it includes thermal comfort improvement for a temperate climate. Likewise, in [27] Kaushink and Kaw, encapsulated water in concrete is used to take advantage of its low cost and its great heating capacity.

The above-mentioned specific examples show that there is not much research about this topic. The studies are limited to the impact of these walls on the building envelope and comprehensive studies of its behavior are not developed. As it is possible to see, most research is done on information about storage in solid and phase change materials. However, there are not many studies which verify the use of water as a possible material and, in this way, they put aside its heat capacity $(4.186 \mathrm{~kJ} / \mathrm{kg} \mathrm{K})$, its attributes in relation to loading and discharge dynamics of the stored energy, and its low cost. The reason why water is not widely used could be related to how to store it within the concrete and to the lack of knowledge about its operating dynamics. This is why this work deals with the use of encapsulated water within solid concrete pieces, as described below.

It is important to design and propose innovative and passive technological solutions for social housing, responding to the limited development of systems combining solid and liquid materials in the storage mass. This work presents the development of heat storage walls (HSW) with mixed storage mass, made of industrialized concrete pieces with water pipes. These aspects make it possible to increase the heat load rate and the energy storage capacity. These systems are presented as an economical and easily replicable alternative in contexts such as mass construction housing. Similarly, a detailed analysis of the technology and its design is shown to collaborate with the development of comprehensive studies on the impact of this technology in habitable spaces.

\section{Objectives and scope}

The objective of this work is to design, simulate and empirically evaluate the mixed heat storage walls thermal behavior, applicable to mass social housing built by the State. Likewise, it is expected to establish the first theoretical-experimental conclusions, involving the functioning and economic-efficient aspects.

The scope of this work involves a first study on the capacity of solid and liquid storage mass, and on the thermal potentialities to combine both types of storage mass. Later, different geometrical shapes and materials for the thermal storage walls are proposed, and a thermal behavior analysis based on thermal simulations of the habitable spaces is carried out, comparing the proposed systems with the most spread ones: solid concrete systems. From that point, the most convenient geometrical shape is chosen and an experiment at a reduced scale is designed to assess thermal performance and the operating dynamics of the walls. The results of this experiment and the system loading efficiency are analyzed. In the last stage, future developments of the current research are proposed.
The article is divided into four sections. The geographical region of implementation, the used materials and methods, and the adopted technological definitions are described within the section called Methodology. Afterwards, the results and discussion are exposed. The thermal simulations, the experimental measurements, the system loading effeciency the economic performance, and the description of future developments are also included in that section. The conclusions are presented in the final segment.

\section{Methodology}

In this section, the geographical region of implementation of the designed technologies, the materials and methods, and the technological definition of the systems are described.

\subsection{Geographical region of implementation}

The Republic of Argentina has a wide climatic diversity and solar availability because of its land area (between $20^{\circ}$ and $60^{\circ}$ south latitude), and because of its geographical diversity (plains, plateaus, and mountains).

The region called Centre of the Province of Buenos Aires is a cold temperate region in accordance with the National Standards IRAM 11603 [28], and it is the most populated province of Argentina. In this climatic region, the total annual horizontal global solar radiation in winter is $4500 \mathrm{MJ} / \mathrm{m}^{2}$. There is also wide thermal amplitude, average humidity, and high and stable relative sunshine duration in comparison with coastal zones in the same province (City of La Plata), where this research group had experience in the development of liquid-filled storage walls. In this climatic context, the Institute of Housing of the Province of Buenos Aires [Instituto de la Vivienda de la Provincia de Buenos Aires - IVBA] proposes the research group to design bioclimatic social housing in this region, especially in the City of Tapalqué, Buenos Aires, Argentina [29]. In Table 1, it is possible to observe the climatic parameters registered by the closest weather station to the city of Tapalqué (city of Azul) and the comparison with the coastal city of La Plata.

As from the climatic analysis of the region of implementation based on our own records and on others', heat storage walls with the following characteristics were considered: more heating load rate, more thermal capacity and inertia, levels of thermal lag of between four and six hours, and semi-controlled heat transfer. Likewise, the possibility of replicating this technology in housing construction in regions with a similar climate in the Republic of Argentina was proposed. Considering the analysis of national and international records in relation to different wall storage mass, the decision was to adopt the use of mixed materials, combining the concrete performance with the one provided by the encapsulated water in its interior.

\subsection{Materials and methods}

In order to develop this work, a comparative analysis of the most widespread technology (solid concrete) and the one presented in this work (mixed concrete with encapsulated water) was carried out.

In a first stage, the thermal behavior of a prototype house bedroom heated by HSW was simulated and analyzed with both 
Table 2

Thermal resistance of the materials of the building envelope.

\begin{tabular}{|c|c|c|c|}
\hline $\begin{array}{l}\text { Plastered hollow } \\
\text { brick walls with } \\
\text { External } \\
\text { Insulation Finish } \\
\text { System (EIFS) }\end{array}$ & $\begin{array}{l}\text { Roof corrugated } \\
\text { metal sheets } \\
\text { with } 0.10 \mathrm{~m} \\
\text { thermal } \\
\text { insulation }\end{array}$ & $\begin{array}{l}\text { Hermetical } \\
\text { double-glazing } \\
\text { windows }\end{array}$ & $\begin{array}{l}\text { Floor with } \\
\text { perimeter } \\
\text { insulation }\end{array}$ \\
\hline $1.49 \mathrm{~W} / \mathrm{m}^{2}{ }^{\circ} \mathrm{C}$ & $3.12 \mathrm{~W} / \mathrm{m}^{2}{ }^{\circ} \mathrm{C}$ & $0.32 \mathrm{~W} / \mathrm{m}^{2}{ }^{\circ} \mathrm{C}$ & $0.88 \mathrm{~W} / \mathrm{m}^{2}{ }^{\circ} \mathrm{C}$ \\
\hline
\end{tabular}

technologies with different geometrical shapes. The wall dimensions, however, were respected in both cases $(1.2 \mathrm{~m}$ wide $\times 2.4 \mathrm{~m}$ tall walls). The habitability levels reached in a room were recorded. The transparent coverings of the walls were also assessed (single or double glazing) in order to make the most of the solar resource, considering the thermal losses and gains balance.

For the simulations, the national SIMEDIF software was used for the calculation of the temporary thermal performance of multiroom buildings. In [30-32], the program's calculation assumptions are demonstrated and validated. The simulations were carried out together with INENCO [33]. Such simulations covered a period of 25 winter days considering the average, maximum and minimum outdoor temperatures of $7.7^{\circ} \mathrm{C}, 14.2^{\circ} \mathrm{C}$ and $2.4^{\circ} \mathrm{C}$ respectively (according to Table 1, city of Azul), and solar radiation varying from $5.4 \mathrm{MJ} / \mathrm{m}^{2}$ per day to $10.5 \mathrm{MJ} / \mathrm{m}^{2}$ per day (according to the Republic of Argentina Solar Radiation Atlas) [34]. The same building determinants of the house prototype were considered in all the simulations. These were: exterior envelope totally exposed to solar radiation (without shading); $10 \mathrm{~W} / \mathrm{m}^{2}{ }^{\circ} \mathrm{C}$ (exterior) and $6-8 \mathrm{~W} / \mathrm{m}^{2}{ }^{\circ} \mathrm{C}$ (interior) convective coefficients, $0.025 \mathrm{~m}$ insulation in vertical parametres and floor; and $0.10 \mathrm{~m}$ ceiling thermal insulation (see Table 2) (see house in Fig. 4). For HSW storage mass, 0.95 absorptances of the equator-facing surfaces were considered.

In order to develop the thermal model, the house was divided in the following zones: bedroom, corridor, living room, bathroom, kitchen, greenhouse, and heat storage wall. For all the zones, except for the heat storage walls, the ventilation rate was fixed in $1 \mathrm{ACH}$ (air change per hour) (hermetic aluminum carpentry with rubber weather stripping).

Each type of storage wall was simulated as an additional thermal zone (with $0 \mathrm{ACH}$ ) with a wall connecting that area with the corresponding bedroom. This wall has high absorptance (0.95) on the side affected by solar radiation, and a $10 \mathrm{~W} / \mathrm{m}^{2}{ }^{\circ} \mathrm{C}$ convective coefficient because of the air flow touching the wall by natural convection. Besides, $0.03 \mathrm{~m}^{2}$ thermocirculation vents were considered (approximately $1 \%$ of the wall surface), whose centers are separated by a $2.16 \mathrm{~m}$ distance, and which are supposed to be closed during the night. As the simulation program does not accept the use of variable convective coefficients between the day and the night, a unique $10 \mathrm{~W} / \mathrm{m}^{2}{ }^{\circ} \mathrm{C}$ coefficient applied to the complete day was used (as the openings are closed during the night, this coefficient should be the one with stagnant air). Using a higher coefficient during the night implies that the air in the storage wall will have a slightly higher temperature in the simulation than the one in the real situation (during night hours). Table values were used for the involved materials conductivity, specific heat, and density (except for water conductivity). Due to the convection phenomenon of the liquid inside the pipes, and that this produces a mixture that unifies the water temperature, only one node for the water was considered with high conductivity (in this case, $k=100 \mathrm{~W} / \mathrm{m}^{\circ} \mathrm{C}$ ).

The purpose of the simulations was to develop an approximation to different types of storage walls behavior according to the relation between the solid and the water mass in a bedroom of a house. Consequently, this analysis made it possible to select technologies to carry out experimental tests.
In a second stage, the experimental tests were aimed at empirical measurement to determine the reached temperature levels in the different sections of the HSW pieces and in an internal heated area at a reduced scale. For that purpose, two $1.08 \mathrm{~m}^{3}$ areas were used, whose envelope is made of expanded polystyrene with $22 \mathrm{~kg} / \mathrm{m}^{3}$ density and $0.05 \mathrm{~m}$ thickness, where the solid storage mass and the mixed storage mass were simultaneously tested in winter.

For the experimental tests, an Omega OM-CP 8-channel data acquisition system with type $T$ thermocouples was installed, supported by four 4-channel Hobo micro data acquisition systems, having 24 channels in total. An Eppley PSP pyranometer was also installed to measure solar radiation on the HSW collector plane (vertical at $90^{\circ}$ and facing the equator). During the pieces manufacture, type $\mathrm{T}$ thermocouples were inserted $(\mathrm{Cu}-\mathrm{K})$ inside the concrete and the water pipes. Later, during the HSW assembly, the thermocouples and sensors were placed on the equator-facing sides and on the opposite ones, and also in the interior of the enclosures to record the air temperature. The measuring period took a week in the month of June.

Fig. 1 illustrates the assembly of the two boxes, the transparent coverings and the complete HSW installation. The pieces were assembled on a concrete platform and the thermal bridge was broken in its support area with hardwood blocks and thermal insulation. In both cases, the equator-facing surface was painted with matt black synthetic enamel to achieve the greatest possible absorptance. It is worth mentioning that this color is not usual in the house and it is possible to replace it with high absorptance colors, resorting to esthetic needs. For example, dark blue reduces the solar absorptance from $95 \%$ to $85 \%$ with respect to matte black color [35].

Finally, the information obtained from the experimental tests allowed the thermal efficiency of the charging cycle of each system to be calculated, based on the heating capacity of each wall, the reached thermal difference, and the received solar radiation.

The technological definitions of the systems are described in the following section.

\subsection{Technological definitions of the systems}

The walls were made of industrialized concrete pieces incorporating the water mass in PVC hermetic pipes. Three geometrical and volumetric variations were originally proposed. One of the walls is traditional and made entirely of concrete. The other two are made of concrete with water inserted in PVC pipes using different water proportions and locations inside the cross-sectional area of each concrete piece. Type 1 wall consists of a $0.16 \mathrm{~m}$ water pipe (section) eccentrically located. Type 2 wall has a $0.25 \mathrm{~m}$ water pipe (section) centered in the axis of the piece. Fig. 2 shows the cross-sections of the pieces.

For the design and construction, a modular industrialized system was chosen in order to replicate it in the programs for social housing built by the State (see Fig. 4). The mold design was carried out after the storage pieces dimensions were adjusted to ensure and keep the dimension, standardization, and simplicity assembly guidelines. This process was useful for the serial production of the pieces with high-quality finish, making a correct final assembly possible. In this case, the molds were made of folded sheet metal but they could also be made of wooden formwork in order to be used in small-scale isolated applications. The dimensions of the entire walls were established in $1.2 \mathrm{~m}$ wide $\mathrm{x} 2.4 \mathrm{~m}$ tall. They are built with $1.2 \mathrm{~m} \times 0.36 \mathrm{~m} \times 0.24 \mathrm{~m}$ pieces, piled up in ten units to obtain the desired height. The standard architectural modulations of mass construction housing were respected, considering an energy contribution capable of meeting the basic demand. Fig. 3 shows the mold, the water pipes, and the storage pieces filling. 


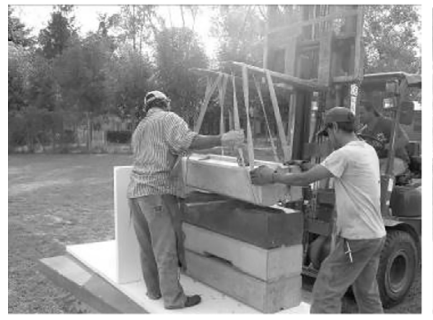

(a)

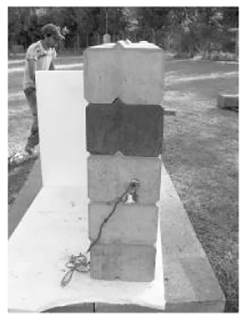

(b)

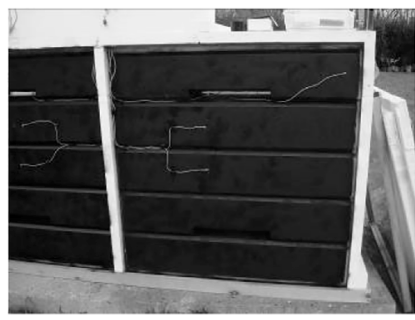

(c)

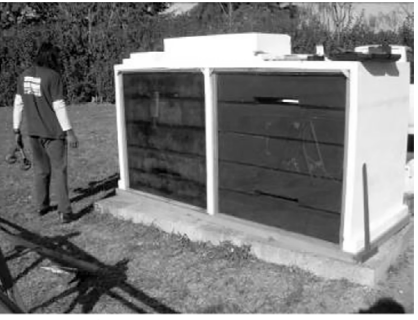

(d)

Fig. 1. (a) Measuring spaces assembly with the complete installation of both HSW. (b and c) Thermocouples location. (d) Transparent coverings installation.

Concrete HSW

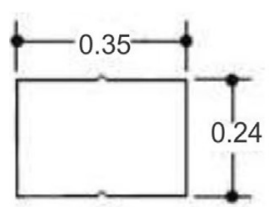

HSW Type 1

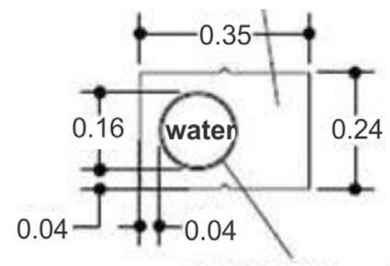

PVC pipes

Ø: $160 \mathrm{~mm}$

Thickness $4.7 \mathrm{~mm}$
HSW Type 2

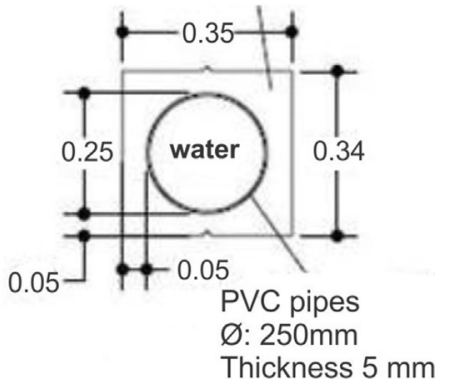

Fig. 2. Cross-sections of the pieces which make three types of HSW.

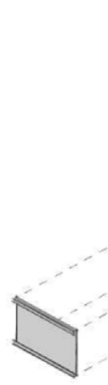

(a)

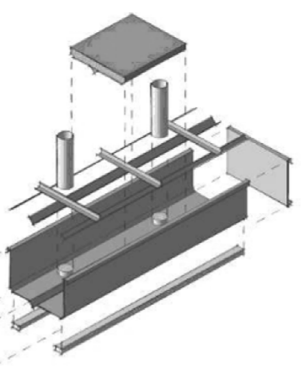

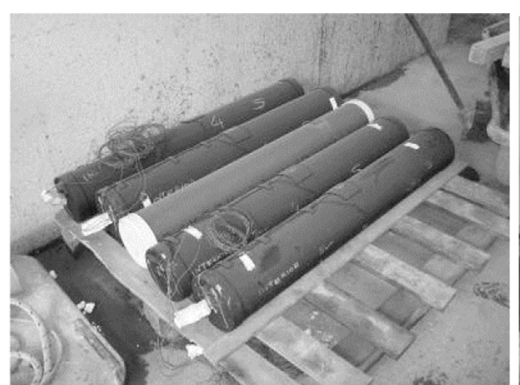

(b)

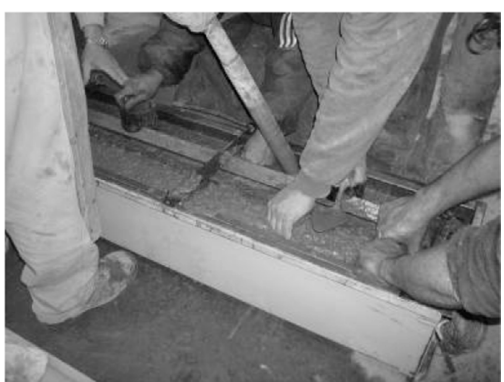

(c)

Fig. 3. (a) The mold; (b) Water pipes; (c) Concrete and water pieces vibration and filling.

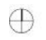

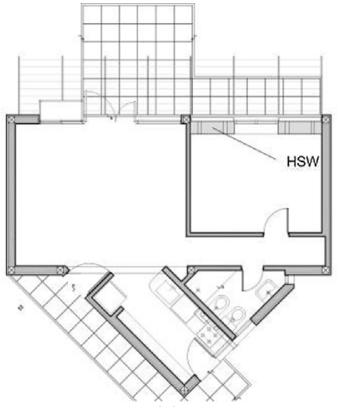

(a)

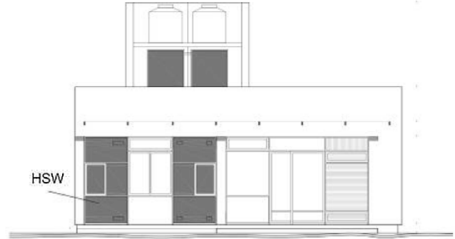

(b)

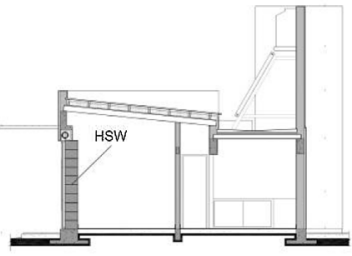

HSW located in dwelling's bedroom

(c)

Fig. 4. Storage walls location in the house. (a) Floor plan; (b) Equator-facing surface; (c) Cross section.

All the pieces have two transverse boreholes to join them with concrete and to unify the storage mass with the structural beam during assembly, in order to give stability to the system. The pieces are joined with commercial standard adhesives. Regarding the materials, $\mathrm{H} 30$ concrete was used (i.e. $300 \mathrm{~kg} / \mathrm{cm}^{2}$ allowable stress $(\sigma)$ ) with $6 / 20$ stone (i.e. the particle size is between 6 and $20 \mathrm{~mm}$ ). The setting time per component was one day and a half. The water has been treated with products used to avoid bacterial proliferation, and it does not have corrosion problems because it has been neutrally encapsulated. The liquid occupies $98 \%$ of the pipe and leaves $2 \%$ of air in its interior. The pipe is closed with covers sealed with fluxing adhesives (special for PVC) and it is inserted before filtering the vibrated concrete pieces, making it virtually hermetic (Fig. 5). The pieces have been exposed to the exterior for seven years and no liquid leaking problems in the interior of the pieces have been registered. 


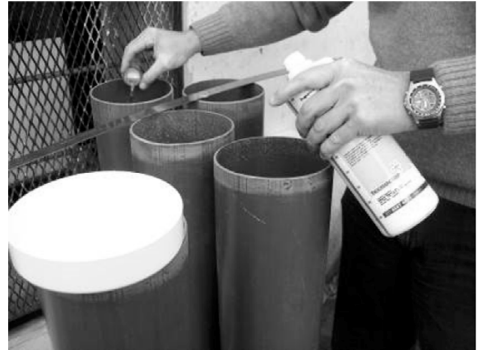

(a)

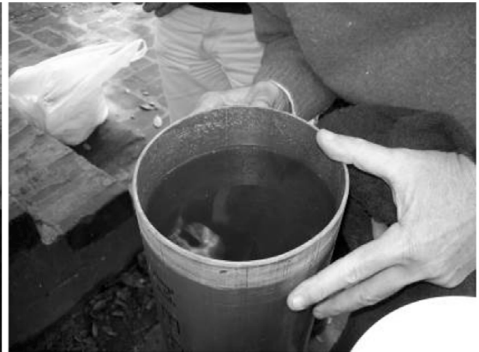

(b)

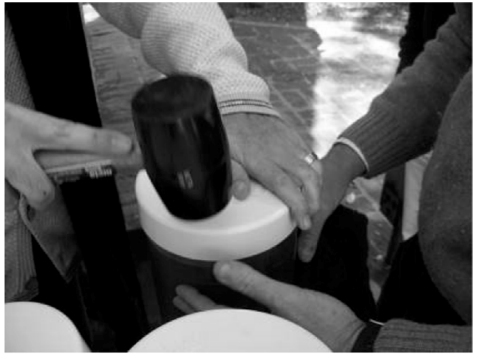

(c)

Fig. 5. (a) Water pipes filling with algicide; (b) Water level in the pipes; (c) Pipes closing and sealing with PVC special covers.

\section{Bedroom temperatures with diferent types of HSW}

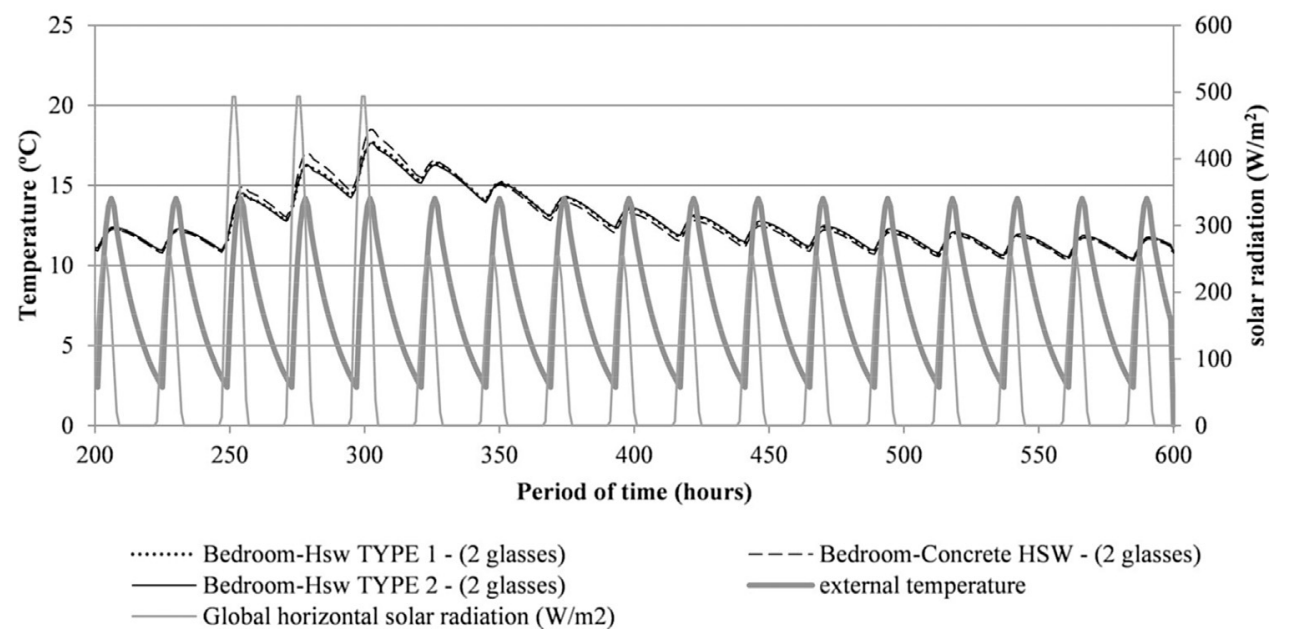

Fig. 6. Comparison of the temperature of the bedroom heated by the three types of storage walls.

In the following section, the results obtained in the simulations, the experimental measurements, and the efficiency calculations of the system are described.

\section{Results and discussion}

\subsection{Thermal simulations}

In order to analyse the results obtained during the thermal simulation, it is necessary to provide some clarifications about each type of storage mass modeling. The characteristics of the simulated models are the following:

- The concrete storage wall is simulated as only one wall, with the concrete thermal characteristics.

- For the type 1 storage wall, the wall connecting the storage wall air with the bedroom was divided into two walls. One wall made only of concrete (with $0.35 \mathrm{~m}$ thickness and an area representing $33 \%$ of the total area of the wall); and the other formed by three layers with different thickness $(0.04 \mathrm{~m}$ of concrete, $0.16 \mathrm{~m}$ of water, $0.15 \mathrm{~m}$ of concrete, with an area of $67 \%$ of the total area of the wall).

- For the type 2 storage wall, the procedure is similar to the previous case. The wall is divided into two walls. One made only of concrete (with an area of $28.6 \%$ of the total area of the wall); and another formed by three layers with different thickness $(0.05 \mathrm{~m}$ of concrete, $0.25 \mathrm{~m}$ of water, $0.05 \mathrm{~m}$ of concrete, with an area of $71.4 \%$ of the total area of the wall).
In relation to the internal gains, the simulation did not consider the house occupation or equipment contribution. However, the solar gains for the storage walls contribution and for direct gain are considered, according to the house design.

In Fig. 6, there is a comparison of the obtained temperatures in the bedroom of the house exposed to the exterior, heated with the three types of walls: concrete, type 1 and type 2, in order to assess which of them provides the highest thermal contribution.

It is observed that the two types of mixed walls (type 1 and type 2 ) result in similar temperatures in the bedroom. Type 1 wall shows a slight improvement in comparison to type 2 wall. In relation to the solid concrete wall, interior temperature levels are slightly higher $\left(\sim 1^{\circ} \mathrm{C}\right)$ than the ones generated with the mixed walls on sunny days. This is because, by not including water inside pipes in the interior, the temperature increases a little bit more when absorbing solar radiation. On sunny days, by using concrete walls, the bedroom temperatures surpass the minimum level of comfort for winter established by local regulations $\left(18^{\circ} \mathrm{C}\right)$. While in the mixed wall, the reached levels were lower $\left(16^{\circ} \mathrm{C}\right)$. It is worth mentioning that in Argentina there is a high percentage of houses which do not even reach the minimum comfort level established by local regulations. On partly cloudy days, the temperature in the bedroom including the concrete wall is slightly lower than the one obtained with the mixed walls. This shows that mixed walls have a similar thermal performance to one made of concrete with the same dimensions. In Fig. 7, type 1 mixed wall is assessed using single and double glazed covering.

In relation to the type of transparent covering, Fig. 7 shows the benefits of type 1 wall (mixed and with eccentric water) with single glazing, and it is compared to the same wall with double glazing. 
Bedroom temperature with HSW Type 1

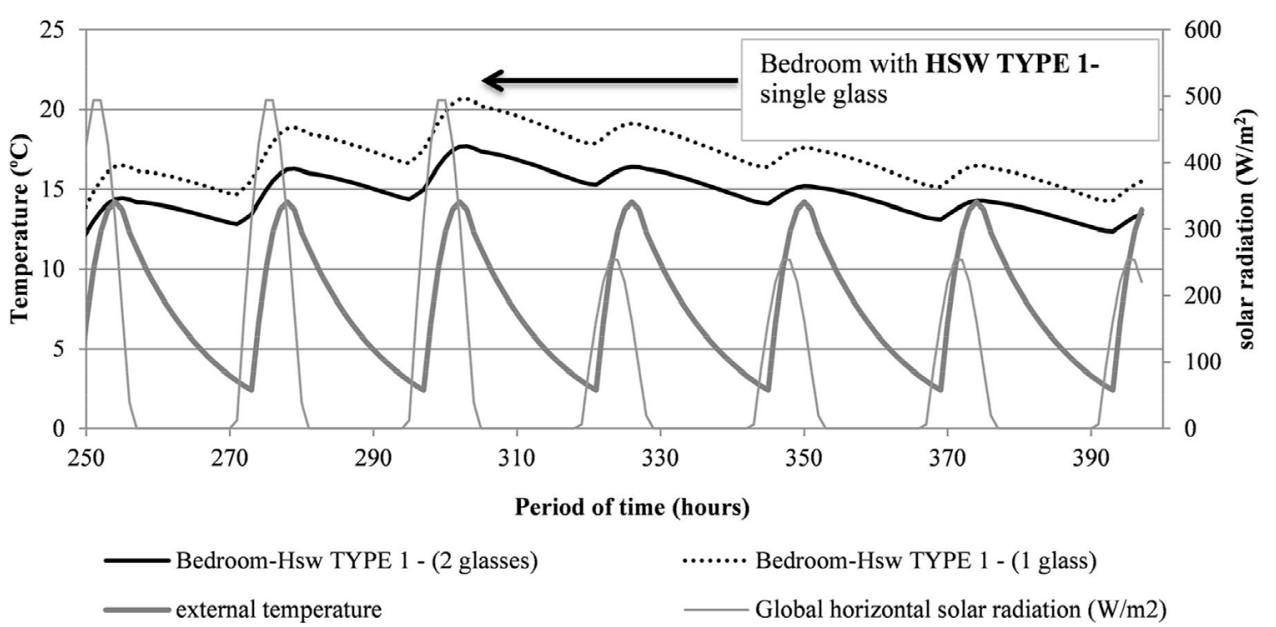

Fig. 7. Thermal behaviour of the bedroom heated with type 1 wall with single and double glazed covering.

COMPARISON: Temperatures inside the enclosures with concrete and mixed material HSW- June 7th to June 14th, 2011.

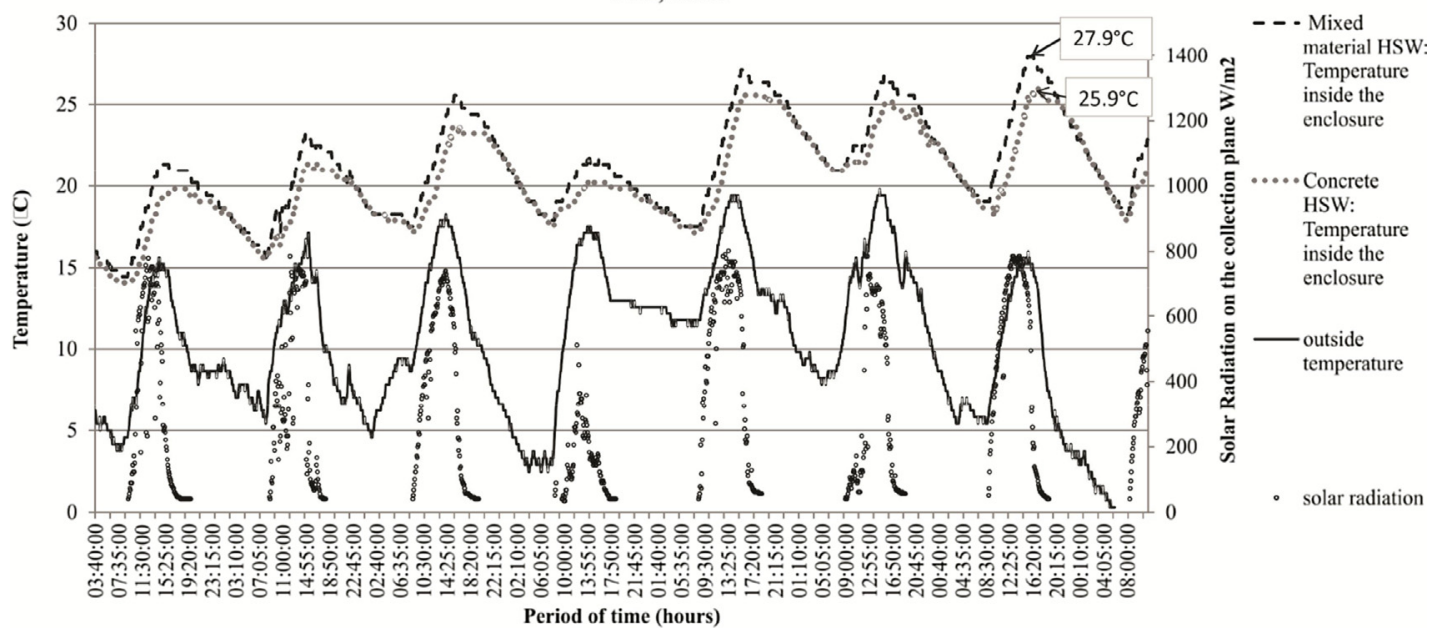

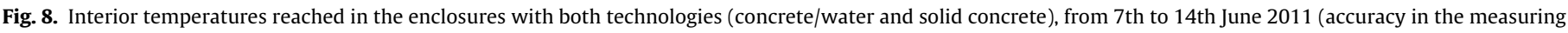
instruments $+-0.5^{\circ} \mathrm{C}$ ).

This is because winter climate is not so severe and the solar radiation availability is low in the area of implementation. Therefore, the use of double glazing significantly reduces the system storage capacity. This is why the use of single glazing and the incorporation of night protection are better to avoid unwanted losses in temperate climates.

To conclude, by comparing the thermal behavior of the analyzed systems, the simulations recorded not very significant differences in favor of the mixed wall. They also helped to determine the use of single glazing as a transparent covering.

From the preliminary simulations, the decision was to opt for the Type $1 \mathrm{HSW}$, and to build mixed pieces (type 1, concrete/encapsulated water in PVC pipes eccentrically placed) and solid concrete pieces for the tests. Type 1 wall has a heat capacity of $822.9 \mathrm{~kJ} / \mathrm{m}^{2}{ }^{\circ} \mathrm{C}(55.8 \mathrm{~kg}$ of water and $641.1 \mathrm{~kg}$ of concrete per $\mathrm{m}^{2}$ ) and an average thermal resistance of $0.50 \mathrm{~W} / \mathrm{m}^{2} \mathrm{~K}$. Whereas in the solid wall, the heat capacity is $702.5 \mathrm{~kJ} / \mathrm{m}^{2}{ }^{\circ} \mathrm{C}\left(763.9 \mathrm{~kg} / \mathrm{m}^{2}\right.$ of concrete per $\mathrm{m}^{2}$ ) and the thermal resistance is $0.39 \mathrm{~W} / \mathrm{m}^{2} \mathrm{~K}$. It is observed that the type 1 wall has more heat capacity and that the water pipes eccentricity will allow the mass storage with high heat capacity to be closer to the sun-facing side. Therefore, the load- ing process will speed up, the temperature levels will increase, and most of the solid concrete mass will be left in the rear part with the aim of maintaining the phase change of the thermal wave between daytime and nighttime cycles.

The test of both types of walls will allow us not only to empirically verify the theoretical results and to experiment with the building and material alternatives, but also to detail their thermal performance and the operating dynamics.

\subsection{Experiments}

In this stage, indoor air temperatures of an insulated enclosure and the reached temperatures in the storage pieces section were analyzed. Fig. 8 illustrates the temperatures reached in the interior of the enclosures heated by both technologies (type 1 concrete/water and solid concrete), during a cycle of seven days in a row with a different amount of sunshine duration and solar radiation.

By comparing both technologies, it is possible to observe a $2{ }^{\circ} \mathrm{C}$ difference in the maximum interior temperature and a $1.2^{\circ} \mathrm{C}$ difference in the minimum interior temperature during all the measured 


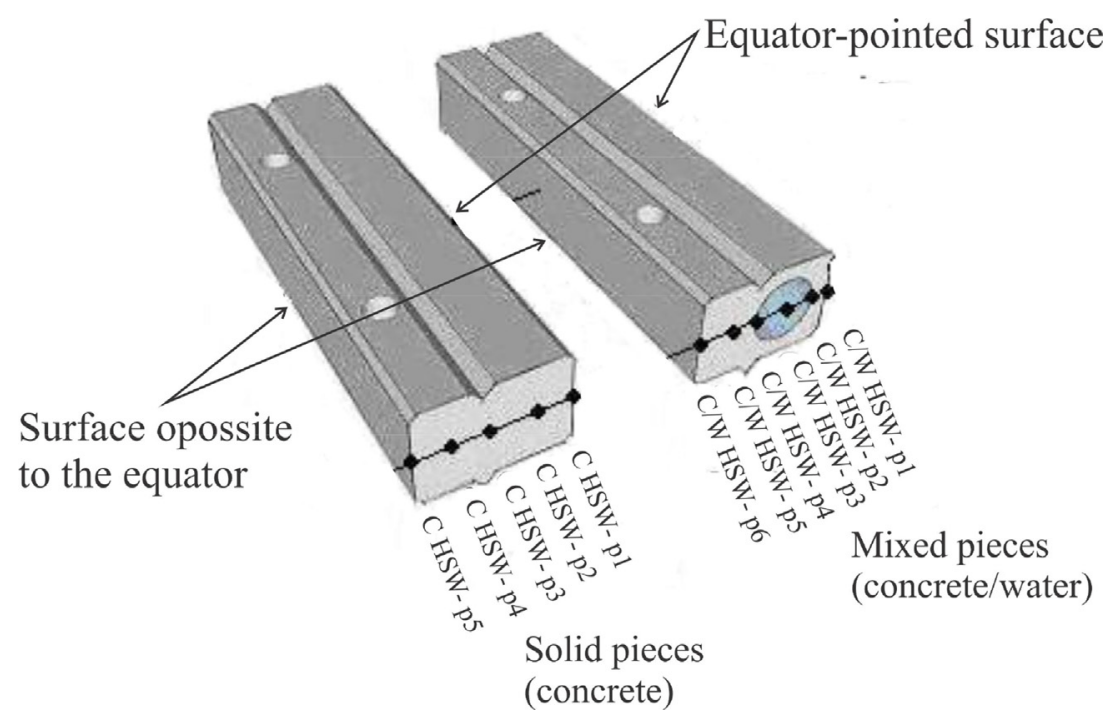

Fig. 9. Measuring points location in the storage wall pieces. Note: C-HSW: concrete storage wall, C/W-HSW: concrete and encrypted water mixed storage wall.

cycle. The maximum temperatures were $27.9^{\circ} \mathrm{C}$ and $25.9^{\circ} \mathrm{C}$ in the mixed wall and in the concrete wall respectively. The minimum temperatures were $19.4^{\circ} \mathrm{C}$ and $18.3^{\circ} \mathrm{C}$ in the mixed wall and in the concrete wall respectively. Those differences are seen during the daytime loading period since the temperatures are put on the same level in the heat transfer period (afternoon-night). This behavior of the slopes of the curves is because the enclosures do not have thermal inertia in the envelope and, as a consequence, they do not store the gained heat. At this stage, it is possible to observe that the simulations were not sensitive enough to spot the differences that were later verified between the solid and the mixed walls. As for the thermal levels reached in the modeled enclosures, they were considered acceptable, because they were over the minimum level of winter thermal comfort established by the Argentinian air conditioning regulations (minimum $18^{\circ} \mathrm{C}$; medium $20^{\circ} \mathrm{C}$; maximum $22^{\circ} \mathrm{C}$ ).

In order to compare the behavior of each HSW storage mass in particular, the results of a winter day cycle on a sunny day in June were analyzed (with a relative sunshine duration higher than $70 \%$ ). Fig. 9 shows the location of the measuring sensors. The following figures show the sequence of temperatures reached in the interior of the walls and in the interior of the enclosure in relation to the exterior temperature and radiation on the vertical plane facing the equator. They always compare the solid concrete wall with the mixed wall. Fig. 10-12 show: i. the HSW equator-facing surface, ii. the HSW internal section, iii. the surface opposite the equator, respectively.

Fig. 10 shows that the slopes of both curves have a similar thermal behavior. The temperatures at the beginning of the solar radiation impact are higher in the wall containing water, while in the temperature peak they are higher in the concrete wall $\left(1^{\circ} \mathrm{C}\right.$ more). This shows a difference between the minimum and the maximum temperatures that is bigger in the solid concrete wall than in the water and concrete wall. Likewise, it is observed that the mixed concrete and water pieces have an early heat transfer process towards the interior (they release the heat one hour before). This difference in the air enthalpy is sustained over time. As a result, the air in the interior of the room has a higher temperature. During the night, the temperatures of the surface facing the equator are $1{ }^{\circ} \mathrm{C}$ higher in the wall containing water. For this reason, there is a higher final loading level.

In Fig. 11, it is observed that the wall containing water presents a previous temperature increase higher on the equator-facing side of

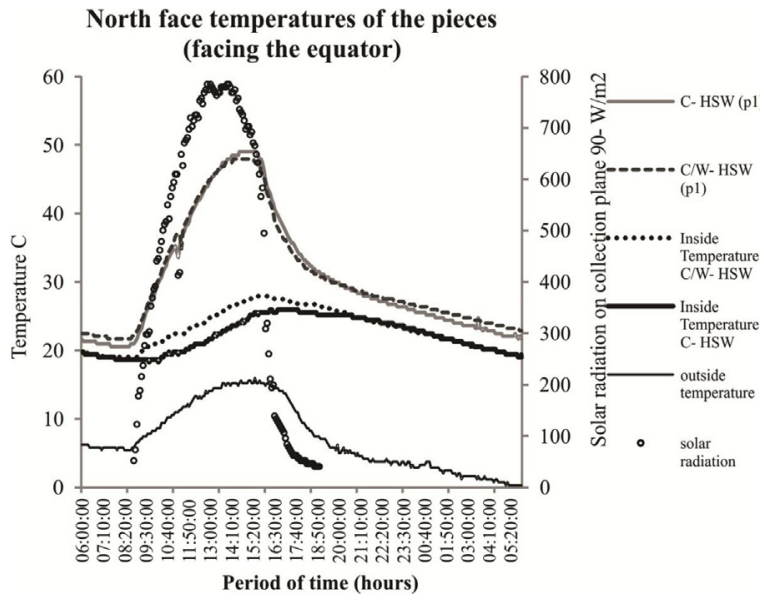

Fig. 10. Temperatures obtained in the equator-facing side of the pieces (accuracy in the measuring instruments $\left.+-0.5^{\circ} \mathrm{C}\right)$. Note: $\mathrm{C}-\mathrm{HSW}$ : concrete storage wall, $\mathrm{C} / \mathrm{W}-\mathrm{HSW}$ : concrete and encrypted water mixed storage wall.

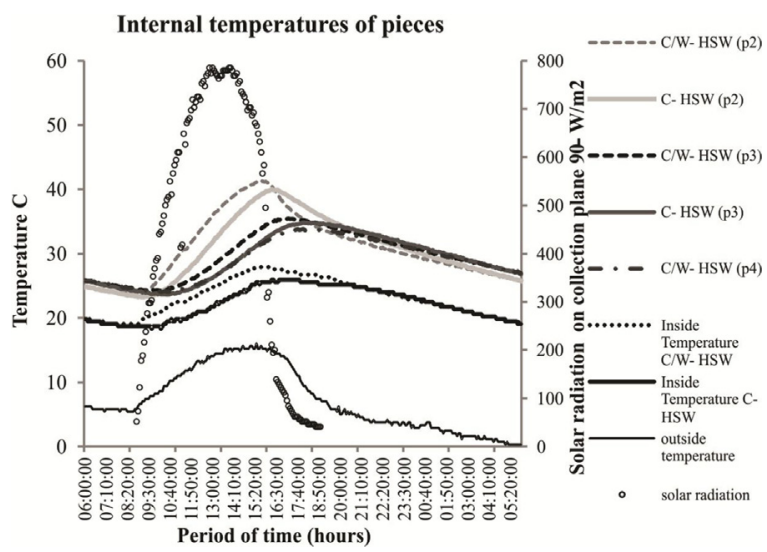

Fig. 11. Temperatures obtained in the interior of the pieces (accuracy in the measuring instruments $+-0.5^{\circ} \mathrm{C}$ ). Note: $\mathrm{C}-\mathrm{HSW}$ : concrete storage wall, $\mathrm{C} / \mathrm{W}-\mathrm{HSW}$ : concrete and encrypted water mixed storage wall.

the water pipe (mixed HSW point 2) than in the concrete wall. However, the thermal difference is lower in the central part and on the south face of the pipe because of the heat wave movement towards 

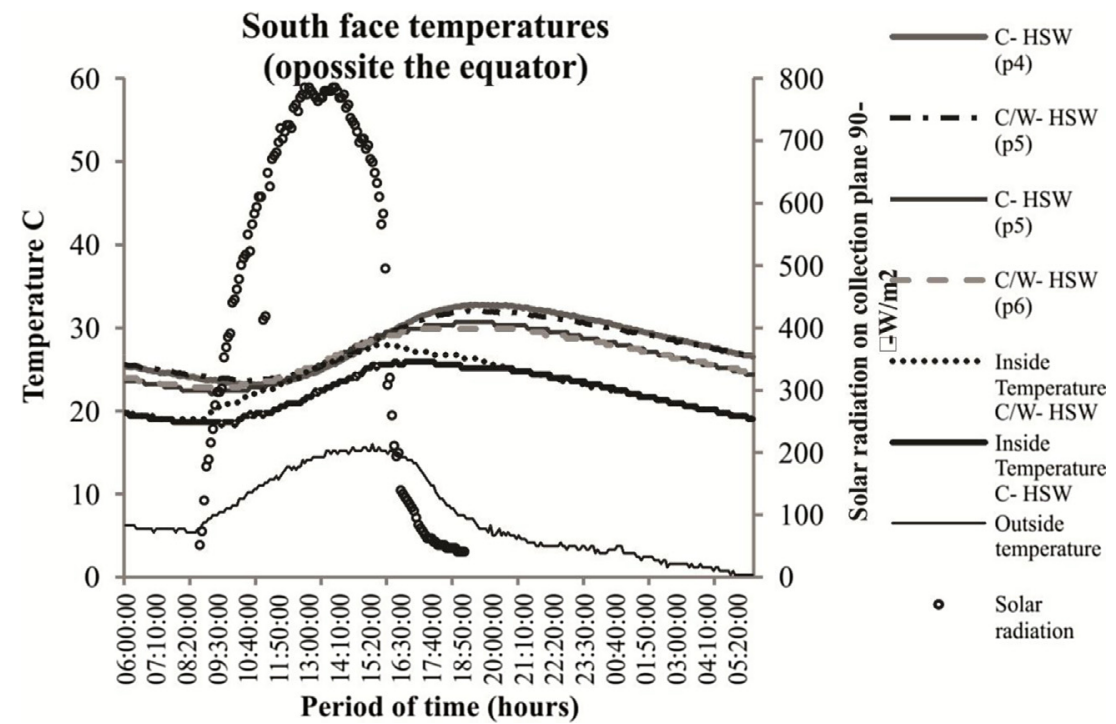

Period of time (hours)

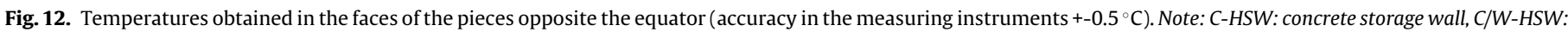
concrete and encrypted water mixed storage wall.

the interior of the enclosure. When the solar radiation impact finishes, the temperatures are lower than in the concrete wall because of the different transfer dynamics between the liquid and the solid storage. In the case of the concrete walls, there is a longer thermal lag of the heat wave determined by its own thermal inertia, and a lower temperature gradient is observed between the points in each section. In the heat release stage, a similar temperature gradient in both sections of the walls is noticed (point 4 in mixed HSW and 3 in solid HSW).

In Fig. 12, both types of walls have a similar behavior, with a maximum temperature slightly higher and a minimum temperature slightly lower in the concrete wall.

From the previous analysis, we can draw the following conclusions. Although there were higher temperatures on the equator-facing surface of the wall containing water, both walls presented similar behaviors on the opposite face. If we relate these behaviors with the temperature in the interior of the enclosures (higher in the wall containing water than in the one with concrete), it is possible to suppose that the heat release dynamics in the wall containing water is better than in the solid one. It is also possible to suppose that the thermal contribution getting in through the openings (thermo-circulation vents) at the top and in the bottom of the wall becomes vitally important since they transfer the heat collected from the superficial and internal gain near this face by natural convection.

As from the preliminary tests, the loading efficiency of each system was analyzed. For that purpose, a sunny day from the measured period was chosen and the following factors were considered: storage mass per $\mathrm{m}^{2}$ of both technologies, the incident energy on the vertical plane (facing the Equator), and the mass temperature daily increase (average value taken from all the maeasuring points in the wall section, according to Fig. 9). With the incident solar energy and the useful energy stored in each wall mass, the general loading efficiency for each case was obtained. Table 3 shows the data considered for the calculation and the obtained results per $\mathrm{m}^{2}$ of wall.

The obtained efficiency when combining both materials is higher than the one of the solid concrete wall. The empirical results verify bigger thermal contributions and a better final efficiency in the mixed storage walls.

Even though the results show differences in the loading dynamics and in the heat capacity between the pieces of both technologies (concrete and concrete with water), there are operational advantages in relation to the heat transfer between the storage mass and the interior air, and to the final load capacity.

In order to complement the general loading efficiency analysis of each type of wall, an assessment of the costs and the obtained benefits was carried out.

\subsection{Economic analysis of the systems}

For this analysis, the materials of each type of wall and different workforce are considered. According to the cost of each piece, the storage wall cost per $\mathrm{m}^{2}$ is calculated. For the economic performance calculation, the following information is required: $i$. the loading efficiency obtained from Table 2; ii. the average daily radiation for winter calculated with the Liu and Jordan method; iii. the stored energy in the wall calculated according to the loading efficiency and daily radiation; iv. the walls' useful life estimated in 30 years (similar to the useful life of traditional housing in Argentina). Therefore, the economic performance considers the cost in dollars of each energy unit $\left(\mathrm{MJ} / \mathrm{m}^{2}\right)$ stored by the wall during the winters along its useful life. This value could be compared with the cost of conventional energy units used for heating a room. The results are observed in Table 4.

The results show that the storage walls containing water have a higher cost per square meter than the solid walls because the cost for the water pipes is included and workforce costs are also higher. However, the difference is not significant (6.3\%), and the higher loading efficiency in the water/concrete wall results in a similar economic performance. This means that the energy unit has similar costs in both walls. To conclude, it is possible to determine that the choice of one or the other system will depend more on the heat release dynamics and on the volumetric heat capacity of each of them rather than on the loading or economic performance.

Empirical results also showed differences between the mixed and the solid wall in the way heat was released. According to this last analysis, it is possible to expect that the economic performance varies if the walls' general performance is considered (including heat dissipation into the indoor air). We expect to advance on this topic after making empirical measurements of the systems incorporated to the houses. 
Table 3

Heat storage walls general loading efficiency on sunny days.

\begin{tabular}{|c|c|c|c|c|c|c|c|c|}
\hline Type of storage & Mass $\mathrm{kg} / \mathrm{m}^{2(\mathrm{a})}$ & $\begin{array}{l}\text { Specific heat } \\
\mathrm{kJ} / \mathrm{kg}^{\circ} \mathrm{C}^{(\mathrm{b})}\end{array}$ & $\begin{array}{l}\text { Heat Capacity } \\
\mathrm{kJ} /{ }^{\circ} \mathrm{C} \mathrm{m}^{2}\left(\mathrm{c}^{2} \mathrm{a}^{*} \mathrm{~b}\right)\end{array}$ & $\begin{array}{l}\text { Mass temperature } \\
\text { daily increase }{ }^{\circ} \mathrm{C}^{(\mathrm{d})}\end{array}$ & $\begin{array}{l}\text { Useful s } \\
\text { energy }\end{array}$ & $\mathrm{n}^{2\left(\mathrm{e}=\mathrm{c}^{*} \mathrm{~d}\right)}$ & $\begin{array}{l}\text { Incident solar } \\
\text { energy } \mathrm{kJ} / \mathrm{m}^{2}\end{array}$ & $\begin{array}{l}\text { Loading } \\
\text { Efficiency } \eta\end{array}$ \\
\hline Water/Concrete & 55.8 & 4.18 & 233.34 & 11.6 & 2713.7 & 9300.8 & 16573 & 0.56 \\
\hline wall & 641.1 & 0.92 & 589.54 & 11.2 & 6578.1 & & & \\
\hline Concrete wall & 763.9 & 0.92 & 702.47 & 12.2 & 8588.4 & 8588.4 & 16573 & 0.52 \\
\hline
\end{tabular}

Ref.: $\eta=$ Useful stored energy/Incident solar energy.

Table 4

Economic performance calculation of the two assessed storage walls.

\begin{tabular}{|c|c|c|c|c|c|c|c|}
\hline HSW Type & $\begin{array}{l}\text { Cost } \\
\left(\$ \mathrm{US} / \mathrm{m}^{2}\right)\end{array}$ & $\begin{array}{l}\text { Loading } \\
\text { efficiency }\end{array}$ & $\begin{array}{l}\text { Winter daily average } \\
\text { radiation }\left(\mathrm{MJ} / \mathrm{m}^{2}\right)\end{array}$ & $\begin{array}{l}\text { Stored energy } \\
\left(\mathrm{MJ} / \mathrm{m}^{2}\right)\end{array}$ & $\begin{array}{l}\text { Useful life of the } \\
\text { wall (years) }\end{array}$ & $\begin{array}{l}\text { Number of } \\
\text { winter days }\end{array}$ & $\begin{array}{l}\text { Economic performance } \\
\text { (\$US/MJ) }\end{array}$ \\
\hline Water/concrete wall & 486 & 0.52 & 11.32 & 6.34 & 30 & 92 & 0.0278 \\
\hline Concrete wall & 455 & 0.56 & 11.32 & 5.89 & 30 & 92 & 0.0280 \\
\hline
\end{tabular}

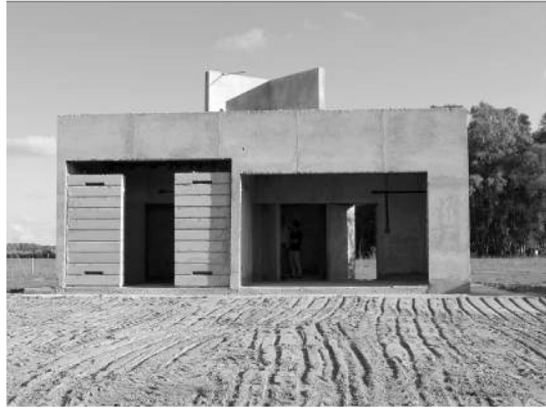

(a)

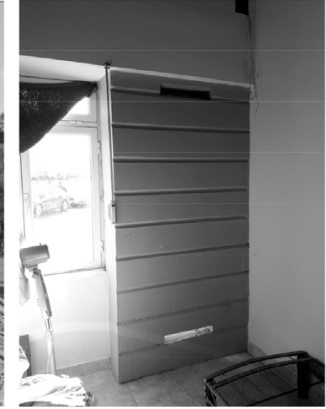

(b)

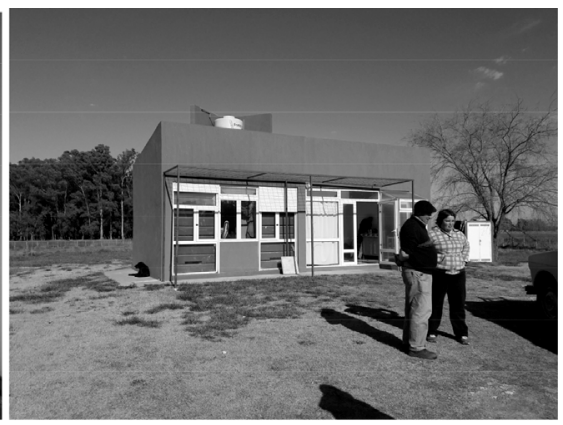

(c)

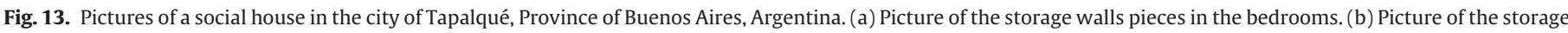
wall in the interior of the bedroom. (c) Picture of the exterior of the house with the finished walls.

\subsection{Future tests}

The technologies described in this work were adopted within the framework of an agreement between the "Instituto de Investigación y Políticas del Ambiente Construido" (IIPAC-FAUUNLP/INENCO-CONICET), "Instituto de la Vivienda de la Provincia de Buenos Aires" (IVBA), the City of Tapalqué in the Province of Buenos Aires, and the "Instituto Nacional de Tecnología Industrial" (INTI). The purpose of this project was the design, modeling, calculation, building and post-occupancy analysis of social housing with bioclimatic technology, based on the implementation of a model with multifactorial management. Fig. 13 shows the building stages.

In view of the completion of the housing construction and their subsequent distribution to the users, it is planned to carry out postoccupancy tests in order to continue with the final assessment and verifications of: $i$. The total thermal load capacity for different sunshine duration and temperatures; ii. the adjustment of the system efficiencies; iii. the delay levels of the thermal wave. Likewise, these tests will be useful for verifying and adjusting the simulation models opportunely developed in the pre-design stages of the systems.

With the obtained results, an invention patent was issued [36] and different alternatives for analysis were defined to continue with the research on the described technologies.

\section{Conclusions}

According to the climatic determinants (temperate zones with a great thermal amplitude higher than $7{ }^{\circ} \mathrm{C}$ ), the working hypothesis was counting on a mixed storage mass for thermal storage walls (concrete with water). This meant having more heat capacity, more energy load rate, good thermal lag of the solid materials; and improving the habitability of the heated spaces. The new tech- nology proposed in this work was compared to the most popular one (concrete solid walls) to assess its thermal behavior and, consequently, to verify the initial hypotheses.

As for construction aspects, it is possible to conclude that industrialization of the storage pieces allowed us to ensure the construction precision, manufacture speed, and assembly simplicity. It was observed that, by respecting the housing modular design, it is possible to ensure that the systems are replicated in mass construction housing in a better way.

The thermal simulations showed not very significant differences in the different types of walls, in both the solid concrete walls and the mixed concrete with water walls, in their two geometrical shapes. According to the simulations, the three types of walls have similar thermal responses. This observation was refuted in the experimental measuring stage. Likewise, differences between the use of single glazing and double glazing as a transparent covering were recorded.

The empirical results showed thermal behavior differences between the mixed walls and the solid concrete walls. Even though the maximum temperatures and the shape of the curves registered a similar behavior on the equator-facing surface and on its opposite, differences at the beginning and at the end of the thermal load were observed. From the empirical data, the global loading efficiency was obtained, showing a 5\% improvement in the mixed system in comparison to the solid concrete one.

In the wall containing water, operational advantages were observed in relation to higher heat transfer between the storage mass and the interior air. Higher thermal loading dynamics in the interior section and a higher final load capacity were also observed.

In a first analysis and according to the interior thermal records reached in both measuring sections, it was possible to verify the precepts considered in the initial hypotheses (more storage load 
and transfer rate during the day-night period). It is necessary to continue with the analysis in order to adjust the results and improve the efficiency.

The economic performance analysis made it possible to observe that the cost difference (slightly higher in the concrete/water HSW mixed walls than in the concrete walls) is compensated by the higher loading efficiency and the stored energy in the walls. Therefore, the choice of one wall or the other will depend mainly on the heat capacity and on the required heat release dynamics.

With the preliminary results, it is possible to outline new alternatives for analysis to study the variables at stake: the relationship between concrete and water; transfer and load rate; thermal inertia and lags; convective flow speed; and wall discharge efficiency; among others.

\section{Acknowledgements}

The authors would like to acknowledge the collaboration of Engineer Bernardo Zaslascky and of Arquitect Florencia Zaslascky from BLOKY, a precast concrete factory. They would also like to acknowledge the contribution of Dr. Silvana Flores Larsen and Dr. Alejandro Hernandez from INENCO, Dr. Irene Martini, Specialist Pedro Chevez, and Translators Agustina Gómez Gezzi and Erika E. Wallace for the collaboration with the translation of the present paper.

\section{References}

[1] INDEC, National Institute of Statistics and Census, Censo Nacional de Población y Vivienda. Censo Nacional de Población, Hogares y Viviendas 2010, Censo del Bicentenario, Resultados de $\neg$ nitivos Serie B No. 2, Tomo 1, 2010 vol. 1, Instituto Nacional de Estadística y Censos - INDEC, Buenos Aires, 2012, 378 p http://www.indec.gob.ar/ftp/cuadros/poblacion/censo2010_tomo1.pdf.

[2] A. Gaite, El proyecto de la vivienda económica, Nobuko Publishing House, Buenos Aires, Argentina, 2006.

[3] J.D. Balcomb, J.C. Hedstrom, Determining heat fluxes from temperature measurements in massive walls, The 5th National Passive Solar Conference (1980) 19-26.

[4] J.D. Balcomb, G. Barker, C.E. Hancock, An Exemplary Building Case Study of the Grand Canyon South Rim Residence, NREL/TP-550-24767, National Renewable Energy Laboratory, Colorado, USA, Golden, CO, 1998.

[5] P. Torcellini, N. Long, S. Pless, R. Judkoff, Evaluation of the Low-Energy Design and Energy Performance of the Zion National Park Visitor Center, NREL Report No. TP-550-34607, National Renewable Energy Laboratory, Colorado, USA, Golden, CO, 2004

[6] L. Zalewski, M. Chantant, S. Lassue, B. Duthoit, Experimental thermal study of a solar wall of composite type, Energy Build. 25 (1997) 7-18.

[7] Briga-Sá Ana, Martins Analisa, Boaventura-Cunha José, Carlos Lanzinha João, Paiva Anabela, Energy performance of trombe walls: adaptation of ISO 13790:2008 (E) to the portuguese reality, Energy Build. 74 (2014) 111-119.

[8] Jaber Samar, Ajib Salman, Optimum design of trombe wall system in mediterranean region, Sol. Energy 85 (2011) 1891-1898.

[9] A.A. Hassanain, E.M. Hokam, T.K. Mallick, Effect of solar storage wall on the passive solar heating constructions, Energy Build. 43 (2011) 737-747.

[10] Z.L. Zhang, B.J. Wachenfeldt, Numerical study on the heat storing capacity of concrete walls with air cavities, Energy Build. 41 (2009) 769-773.

[11] G. Lesino, A. Ovejero, L. Saravia, Anteproyecto y análisis térmico de una vivienda con uso de energía solar para la Puna, Publication of the 4th Working Meeting of ASADES (1978) 269-305.

[12] G. Lesino, Requena Saravia, Fontanilla Echazú, Edificios solares en la Puna: estado de avance de su construcción y modelización, Publication of the 7th Working Meeting of ASADES (1981) 138-153.

[13] L. Guerrero, C. Discoli, E. Rosenfeld, O. Ravella, C. Ferreyro, Prototipo experimental de La Plata: primera campaña de ensayos de habitabilidad y comportamiento energético, Publication of the 9th Working Meeting of ASADES (1984) 113-120.

[14] M. Pomianowskia, P. Heiselberga, Y. Zhang, Review of thermal energy storage technologies based on PCM application in buildings, Energy Build. 67 (2013) 56-69.

[15] L.F. Cabeza, C. Castellón, M. Nogués, M. Medrano, R. Leppers, O. Zubillaga, Use of microencapsulated PCM in concrete walls for energy savings, Energy Build. 39 (2007) 113-119.

[16] N. Khalifa Abdul Jabbar, F. Abbas Ehsan, A comparative performance study of some thermal storage materials used for solar space heating, Energy Build. 41 (2009) 407-415

[17] C. Zhang, Y. Chen, L. Wu, M. Shi, Thermal response of brick wall filled with phase change materials (PCM) under fluctuating outdoor temperatures, Energy Build. 43 (2011) 3514-3520.

[18] Bontemps André, Ahmad Maha, Johannès Kevin, Sallée Hébert, Experimental and modelling study of twin cells with latent heat storage walls, Energy Build 43 (2011) 2456-2461.

[19] W. Wang, Z. Tian, Y. Ding, Investigation on the influencing factors of energy consumption and thermal comfort for a passive solar house with water thermal storage wall, Energy Build. 64 (2013) 218-223.

[20] L. Guerrero, E. Rosenfeld, O. Ravella Cueto, Muro colector acumulador para el programa CESAD, Publication of the 5th Working Meeting of ASADES (1979) 491-499.

[21] Solar Architecture Institute, Foundation for Research and Energy Progress, Built Environment Policy Research Institute - National University of La Plata (IAS-FIPE-IIPAC), La casa solar de La Plata, Paidea, La Plata- Argentina, 2009.

[22] C. Discoli, L. Guerrero, E. Rosenfeld, O. Ravella, Muro colector acumulador en agua: su comportamiento en la zona templada-húmeda, Publication of the 10th Working Meeting of ASADES (1985) 15-22.

[23] C. Discoli, E. Rosenfeld, Muro colector acumulador en agua: módulos industrializables de bajo costo, Publication of the 11th Working Meeting of ASADES (1986) 77-84.

[24] S.C. Kaushik, S. Kaul, Thermal comfort in buildings through a mixed water-mass thermal storage wall, Build. Environ. 24 (1989) 199-207.

[25] Alanis Saravia Lesino, Material de alto calor específico para muro trombe-michel, in: Publication of the 4th Working Meeting of ASADES, La Plata, 1978, pp. 241-248.

[26] Gaspar Urriol, Sistema de ensayo comparativo de muros colectores-acumuladores y simulación de un muro Homogéneo, in: Publication of the 6th Working Meeting of ASADES, Catamarca, 1980, pp. 247-272.

[27] Alanis, Saravia, Lesino, Propiedades térmicas y ensayo de materiales para acumulación, in: Publication of the 5th Working Meeting of ASADES, Cordoba, 1978, pp. 67-99.

[28] IRAM Norm No. 11603, Clasificación Bioambiental De La República Argentina, 1996.

[29] G. San Juan, C. Discoli, G. Viegas, C. Ferreyro, L. Rodriguez, L. dicroce, J. Esparza, M.V. Barros, Proyecto de viviendas bioclimáticas de interés social, Tapalqué, Provincia de Buenos Aires, ERMA J. 34 (2014) 1-12.

[30] S. Flores Larsen, G. Lesino, Modelo térmico del programa SIMEDIF de simulación de edificios, ERMA J. 9 (2001) 15-24.

[31] C. Filippın, S. Flores Larsen, E. Lopez Gay, Energy improvement of a conventional dwelling in Argentina through thermal simulation, Renew. Energy 33 (10) (2008) 2246-2257.

[32] S. Flores Larsen, C. Filippin, A. Beascochea, G. Lesino, An experience on integrating monitoring and simulation tools in the design of energy-saving buildings, Energy Build. 40 (2008) 987-997.

[33] S. Flores Larsen, A. Hernández, INENCO, UNSa. Salta, Technical report: Análisis de muros de acumulación de calor mediante simulación térmica, para una vivienda social localizada en zona centro de la Provincia de Buenos Aires, 2010 (Unpublished document)

[34] H. Grossi Gallegos, R. Righini, Atlas de energía solar de la República Argentina, the National University of Lujan and the Science and Technology Secretariat, Buenos Aires, Argentina, 2007.

[35] Mazria Eduard, El libro de la Energía Solar Pasiva, Editorial GG S.A., México, 1983.

[36] C. Discoli, G. San Juan. Patent Muro climatizador Acumulador de Calor Mixto conformado a partir de unidades moduladores, IMPI 20110100010, Patent Office of CONICET, Published in Boletín de patentes AR081517A1, 3 de octubre de $2012,2010$. 